\title{
A General Overview on the Nominal Predicate in English and Albanian Languages
}

\author{
MA Suzana Samarxhiu Gjata \\ Lecturer "Aleksander Moisiu" University, Durres \\ e-mailsmrxh@yahoo.com \\ tel:00355692457734
}

Anisa Koci

Email:anisakoci@yahoo.com

\section{Doi:10.5901/ajis/2013.2n1p399}

\section{Abstract}

The aim of this paper is to make a comparison of the nominal predicate in two different languages, English and Albanian. We have tried to make a general analysis of this part of speech, studying it from the semantic, morphological and syntactical point of view.

Key words: nominal predicate, subject, object, noun, adjective

\section{Introduction}

To treat a theme on nominal predicates, includes a wide scope of knowledge, recognition practices. However, in this paper we tried to present it in more detail and objective uses of predicates nouns in English and Albanian compared with each other.

It presents a variety of uses, so linguists make the nominal predicate occasionally the object of their studies in order to go up to the meaning of any uncertainty regarding its operation, competition with other parts of the speech as well as its segregation in some of its uses.

From the semantic point of view we say that through nominal predicates appear multiple shades affective expression, it represents a process through the lens of speakers giving his personal attitude towards a person or thing.

From the morphological point of view complex nominal predicates is formed from a copular verb and from another part of speech, noun or adjective.

From the syntactic point of view it enters into relationship with the subject or the object in order to form what we call the complex object.

Predicate nominative formed by the copula and the nominal part is a subdivision of the classification made to compound predicates.

\section{Copular verb}

The notion of the copular verbs is a very important research. In English the notion of the copular verb is broader than it is generally accepted in Albanian language. In defining this notion, copular verbs should 
be analyzed according to its semantic and syntactic features.

In both languages,copula which serves as a connector between the subject and the nominal part is meaningless.

It is classified into: a). verbs indicating state and b). verb indicating a change of state. Besides its meaningless, there has been noticed full lexical meaning of these verbs so in this case we have to do with semi- copular verbs. These kinds of verbs were not mentioned ever in today's stage of Albanian language.

"He came home tired".( English)
"Ai erdhi i lodhur". (Albanian)

The verb used in this clause implies two meanings, the fact that he came and his conditions when he came as well. "Tired " is the nominal part which comes after the verb.

A further analyses is done on the nominal part of the clause. We have tried to reflect the common and different features of this part of speech in two languages, English and Albanian.

\section{Nominal predicate}

In both languages the nominal predicate is expressed by a noun to give characteristics on the subject or the object. This noun might be indefinite to show identifying quality or definite to show classifying quality.

When the noun is used definitely, it can change its position in the clause and it can be placed before the predicate in both languages.

The difference between the two languages stands on the use of the noun indefinitely. The indefinite noun in English cannot change its position, whereas the indefinite noun in Albanian language can change the position due to the nature of this language whose elements adapt easily. The nominal part in English expressed by a noun adapts with the subject in number and rarely in gender, whereas in Albanian it adjusts with the subject in gender, number and case.

In both languages, in the function of nominal predicate are used even the pronouns like: interrogative pronouns and indefinite pronouns. The main difference between English and Albanian stands on the personal pronoun. In English language after the copula, the pronoun is mostly used in its objective case whereas in Albanian language, the pronoun is used in its nominal case.

In both languages adjectives have a wider use in the position of the nominal part. In Albanian the adjective is used with or without a "knot".

In English the adjectives don't adapt with the subject or the object, whereas in Albanian they adapt with these parts of speech in number and gender.

The position of the adjectives in both languages is not fixed. Their position is conditioned by stylistic and expressive-emotional factors; in the neutral literary discourse they stand after the predicate, in literary discourse, especially in spoken expressive-emotional coloration discourse they are used before the predicate.

Adverbs are often used in the function of the nominal part in both languages. They enter into discourse as a phrase logical unit, lose their original meaning and location show a quality of the subject.

Some adverbs used in English are: well, alive etc. in Albanian these are called "reliktor" adjectives.

The nominal part enters into relationship even with the object. The object in this case is the socalled the complex-object. The subject in a clause shows quality of the object through the predicative. 
The predicative o the object is expressed by a noun, adjective or noun with preposition. In both languages, the noun in the function of predicative adapts in number. In Albanian language it adapts in gender, but it rarely happens in English. Ex:prince - princess.

The predicative expressed by an adjective, in English, does not adapt with the object. In Albanian language, the predicative adapts with the object in number, gender, case.

When the range of homogeneous parts, there is an object expressed by masculine nouns and pronouns, the predicative expressed by the adjective is used in masculine as the representative gender.

As a conclusion, we may say that the predicative is classified as compulsory or optional in the clause. It is compulsory when it cannot be removed from the sentence as she cannot stand grammatically and semantically. The predicative is optional when it can be easily removed from the sentence without destroying its grammatical structure, but its semantic meaning remains the same.

\section{References}

Akademia e shkencave të Shqipërisë, (1997) Gramatika e gjuhës shqipe II, Tirane

Dhrimo. A. (1969)."Mbi disa çështje të klasifikimit morfologjik të mbiemrave” Studime filologjike Nr.I page 4969

Përnaska. R. (1973) “Gramatika e gjuhës shqipe II për shkollën pedagogjike”, 1973, page. 72

Rrota .J. (1943) "Sintaksa e gjuhës shqipe",page 8

Rrushi. Th. (1987) "Disa çështje të gjymtyrëve të dyta të fjalisë në gjuhën shqipe" Studime filologjike Nr. 3, 1987 page. 123

Sheperi I. (1927) "Gramatika dhe sintaksa e gjuhës shqipe",page I49

Totoni. M. (1976) “Përcaktori Kallëzuesor”,.Studime Filologjike. Nr. 3 page 87-II2

Bernd Kortmann( 2004 ) “Dialectology meets typology: dialect grammar from a cross-linguistic perspective”, 2004 page 6I. Walter de Gruyter\&Co Berl

Den Dicken (2006) "Relators and linkers: the syntax of predication, predicate inversion, and copulas". page 44. Massachusetts

Harvey. M. (2003) “The Nuts \& Bolts of College writing”. page. I5-I6 Hackett Publishing Company, Inc USA

Harrie Wetzer (1996) "The typology of adjectival predication" page I65-I66 Mouton de Gryter Berlin

Heycock , Kroch (2006) "Relators and linkers: the syntax of predication, predicate inversion, and Copulas," page.44. Pullum Cambridge

Higgings (1979) “Copular clauses”, page 204-293

Jespersen. O.( 2006) "Essentials of English Grammar",. page 89-95. George Allan\&Unwin Ltd UK

Laurie Rozakis (2003) "The complete idiot's guide to grammar and style",page.37 McGraw Hill Company United States of America

Leon Stassen 2003 "Intransitive predication", page 62. Oxford University press.

Mikkelsen (2005) "Copular clauses: specification, predication and equation", page. II8 John Benjamins Publishing company

O'Dwyer. B. ( 2006) "Modern English Structures: Form, Function, And Position”, page. 64 Broadview Press Canada

Quirk. (1985) "A Comprehensive grammar of the English language", page I7I. Longman

Rodney D. Huddleston, Geoffrey K. Pullum (2005) "A student's introduction to English grammar" page 77

Simon C. Dik, Kees Hengeveld (1999) "The theory of functional grammar", Volume I, page I93- 202 Walter de Gruyter\&Co Berlin 
